\title{
Hipotik Kapal Laut Dalam Mencapai Negara Kesejahteraan
}

\author{
Fera Indriyati ${ }^{1}$ \\ Faculty of Law, Maranatha Christian University \\ feraindriyati@ymail.com
}

\begin{abstract}
The development of economy is higly influence the prosperity of a state. However, an economic which fully base on market, may not authomatically lead to welfare for all part of society, in opposite, it may extend the gap in society. In order to reduce the gap, a state, including Indonesia, must promote the model of welfare state, a model which give a bigger role to a state or government in regulate a planned, institutionalized, and sustainable economic development. With regard to the geographic of Indonesia as maritime and archipelagic state, the roles of mortgage institution are crucial in developing economic especially in maritime sector as transportation. The problem is, the lack of interest from bank and financial institution to distribute credit to businessman. This article aims to examine and analyze to which extent the role of banking in promoting the prosperity of a community by means of mortgage and ocean vessel as an object of assurance.

This article is a normative judicial research. The author uses analytical descriptive. The author also collects primary and secondary legal material and then analyze both qualitatively.

The result show that the role of banks is eseential to promote welfare state in economic development of Indonesia. Indonesia mus revise the regulation on mortgage and integrate all related regulation so the legal certainty achieved.
\end{abstract}

Keywords: Mortgage; ocean vessel; welfarestate; bank and financial institution.

\section{PENDAHULUAN}

Konsepsi Negara Kesatuan Republik Indonesia adalah negara yang merumuskan konstitusinya dengan falsafah Negara Kesejahteraan (welfare state), dimana Negara harus memberikan perlindungan dan pelayanan sosial kepada

\footnotetext{
${ }^{1}$ Penulis adalah dosen Fakultas Hukum Universitas Kristen Maranatha dan sedang menempuh program S3 ilmu hukum di Fakultas Hukum Universitas Padjadjaran
} 
rakyatnya sebagaimana dimandatkan dalam Pembukaan Undang-undang Dasar 1945 pada alinea ke empat yaitu $:^{2}$

"...membentuk suatu pemerintahan Negara Indonesia dan seluruh tumpah darah Indonesia yang melindungi segenap bangsa Indonesia dan untuk memajukan kesejahteraan umum, mencerdaskan kehidupan bangsa..."

Negara kesejahteraan secara singkat dapat didefinisikan sebagai suatu negara dimana pemerintahan atau Negara dianggap bertanggung jawab dalam menjamin standar kesejahteraan hidup minimum bagi setiap warga negaranya. ${ }^{3}$ Standar kesejahteraan minimum yang dimaksudkan dalam Negara kesejahteraan, adalah memberikan tanggung jawab kepada Negara untuk berperan aktif dalam mengelola perekonomian yang didalamnya mencakup tanggung jawab Negara untuk menjamin ketersediaan pelayanan kesejahteraan dasar dalam tingkat tertentu bagi warga negaranya.

Salah satu tanggung jawab Negara dalam negara kesejahteraan berdasarkan Undang-undang Dasar 1945, adalah peran aktif negara dalam bidang perekonomian dengan mengatur dan mengawasi kegiatan usaha perbankan, termasuk di dalamnya adalah kegiatan perkreditan. Pengaturan dan pengawasan perbankan sangat dibutuhkan, mengingat sebagian besar kegiatan usaha dan pengembangannya menggunakan fasilitas kredit perbankan. Pada asasnya, pemberian kredit mengandung risiko. Oleh karena itu negara melalui pemerintah mengatur prinsip kehati-hatian bank dalam Undang-undang Nomor 10 Tahun 1998 tentang Perbankan (UU Perbankan). Di dalam prinsip kehati-hatian diatur agunan sebagai jaminan tambahan. Mengenai agunan diatur secara khusus dalam berbagai peraturan perundang-undangan yang mengatur jaminan utang yang sering disebut Hukum Jaminan. Ketentuan-ketentuan Hukum Jaminan tersebut akan melindungi pihak-pihak yang berkepentingan dengan pinjaman uang dan jaminan utang tersebut. ${ }^{4}$

Hipotik adalah jaminan kebendaan atas benda tidak bergerak selain tanah, termasuk kapal laut. Khusus hipotik kapal laut diatur dalam berbagai peraturan perundang-undangan dalam berbagai tingkatannya. Hal ini menimbulkan ketidakpastian hukum. Padahal hipotik kapal laut yang dapat memberikan kepastian hukum, akan berbanding lurus dengan kemudahan-kemudahan penyaluran kredit oleh lembaga bank, sehingga dapat meningkatkan kesejahteraan masyarakat dan kemajuan pembangunan pada umumnya dan pembangunan di bidang maritim pada khususnya.

Berdasarkan uraian pada latar belakang tersebut, di atas maka sebagai permasalahannya adalah sejauh mana hipotik kapal laut dapat mencapai tujuan negara kesejahteraan.

2 Otje Salman S dan Anton F Susanto, Teori Hukum (mengingat, mengumpulkan dan membuka kembali), Bandung: Refika Aditama, 2004, hlm .156-157.

${ }^{3}$ Luthfi J. Kurniawan (et.al), Negara Kesejahteraan dan Pelayanan Sosial, Malang: Intrans Publishing, 2015, hlm .56.

${ }^{4}$ M.Bahsan, Hukum Jaminan dan Jaminan Kredit Perbankan Indonesia, Jakarta: Raja Grafindo Persada, 2007, hlm.102. 
Dialogia luridica: Jurnal Hukum Bisnis dan Investasi

Volume 10 Nomor 2, April 2019

\section{PEMBAHASAN}

\section{Hukum Jaminan Dalam Tujuan Negara Kesejahteraan}

Lahirnya GBHN pada orde baru dan Propenas serta RPJPN (Rencana Pembangunan Jangka Panjang Nasional) pada orde reformasi merupakan bentuk dari implementasi konsep atau teori Negara Kesejahteraan di Indonesia yang telah diamanatkan dalam UUD 1945. Amanat Negara Kesejahteraan yang kemudian menjadi dasar negara merupakan hasil dari perjanjian politik pada saatsaat awal mendirikan negara. ${ }^{5}$ Baik GBHN, Propenas maupun RPJPN merupakan landasan hukum bagi pembangunan berkelanjutan bagi bangsa Indonesia, untuk mencapai tujuan nasional Bangsa Indonesia, yaitu melindungi segenap bangsa dan seluruh tumpah darah Indonesia; memajukan kesejahteraan umum; mencerdaskan bangsa; dan Ikut melaksanakan ketertiban dunia yang berdasarkan kemerdekaan, perdamaian abadi dan keadilan sosial.

Negara Kesejahteraan menurut Utrecht terkait dengan prinsip-prinisp negara hukum. Ada dua macam negara hukum, yaitu negara hukum formil atau negara hukum klasik dan negara hukum dalam arti meteriil atau negara hukum yang bersifat modern. Dalam artian formil, tugas negara adalah melaksanakan peraturan perundang-undangan untuk melaksanakan ketertiban atau lebih dikenal sebagai negara penjaga malam (nachtwackerstaats). Sementara dalam artian materiil tugas negara tidak hanya sebatas menjaga ketertiban saja, melainkan juga kehadiran negara adalah untuk mencapai kesejahteraan rakyat untuk mecapai keadilan (welfarestate). Fungsi negara dalam arti meteriil, menjadikan utama bagi sebuah negara adalah bertindak sebagai pelayan masyarakat (public service), dalam rangka meningkatkan kesejahteraan masyarakat tersebut. ${ }^{6}$

Konsep fungsi negara dalam arti materiil, menjadikan negara memiliki fungsi intervensionis. Artinya bahwa negara selalu akan ambil bagian dalam setiap gerak dan langkah masyarakat dengan alasan untuk meningkatkan kesejahteraan umum. Oleh karenanya tugas negara menjadi sangatlah luas dan menjangkau setiap aspek kehidupan masyarakat dalam segala bidang mulai dari sosial budaya, politik, agama, teknologi, pertahanan keamanan, bahkan kalau perlu masuk ke dalam kehidupan privat warga negaranya. ${ }^{7}$

Jimly Asshiddiqie, menyebutkan ada 12 (dua belas) prinsip negara kesejahteraan (welafare stste) Indonesia, sebagai negara hukum modern, salah satunya adalah berfungsi sebagai sarana mewujudkan tujuan bernegara (welfare rechtstaat). ${ }^{8}$ Jimly menekankan bahwa hukum adalah sarana untuk mencapai tujuan yang diidealkan bersama. Cita-cita hukum itu sendiri, baik yang dilembagakan melalui gagasan negara demokrasi maupun yang diwujudkan

5 Luthfi J. Kurniawan, dkk, Negara Kesejahteraan dan Pelayanan Sosial, Malang: Instans Publishing, 2015, hlm. v

6 B. Hestu Cipto Handoyo, Hukum Tata Negara Indonesia, Menuju Konsolidasi Sistem Demokrasi, Jakarta: Universitas Atmadjaya, 2009, hlm. 20

7 Anthony Giddens, The Third Way : Jalan Ketiga Demokrasi Sosial, Jakarta: Gramedia, 1998, hlm. 100

${ }^{8}$ Jimly Asshiddiqie, Gagasa Negara Hukum Indonesia, diakses dari http://www.jimly.com/makalah/namafile/135/Konsep_Negara_Hukum_Indonesia.pdf, pada tanggal 11 September 2017, jam 15.30 
melalui gagasan negara hukum, dimaksudkan untuk meningkatkan kesejahteraan umum. ${ }^{9}$

Cita-cita hukum yang dimaksud adalah dengan secara terus menerus, melaksanakan pembangunan nasional untuk mencapai tujuan bangsa Indonesia mencapai kesejahteraan umum, termasuk di dalamnya di bidang politik, ekonomi, sosial budaya, dan hukum, pertahanan dan keamanan, yang terus dilaksanakan di masa orde baru dengan GBHN dan Repelita-nya, dan di masa orde reformasi dengan Propenas dan RPJP. Tidak terkecuali di bidang perbankan dan jaminan kredit. Pemerintah berperan aktif dengan melakukan intervensi terhadap pelaksanaan hukum jaminan khususnya hipotik kapal laut, dalam rangka menunjang pembangunan ekonomi nasional, lebih khusus lagi untuk khususnya pembangunan ekonomi kelautan.

Intervensi tersebut dilakukan dengan tetap dipertahankannya ketentuan hipotik dalam KUHPerdata dan KUHD, dan diundangkannya berbagai peraturan perundang-undangan yang mengatur hipotik kapal laut seperti Undang-Undang Nomor 17 tahun 2008 juncto Undang-Undang Nomor 21 tahun 1992 tentang Pelayaran (selanjutnya disebut dengan UU Pelayaran); Peraturan Pemerintah Nomor 51 Tahun 2002 tentang Perkapalan (selanjutnya disebut PP Perkapalan); Peraturan Menteri Perhubungan Nomor PM 13/2012 tentang Pendaftaran dan Kebangsaan Kapal (selanjutnya disebut Permenhub 13/2012); Keputusan Menteri Perhubungan Nomor 14 tahun 1996 tentang Penyederhanaan Tata Cara Pengadaan Dan Pendaftaran Kapal; Peraturan Presiden Republik Indonesia Nomor 44 tahun 2005 tentang Pengesahan Internasional Convention on Maritime liens and Mortgages 1993; Instruksi Presiden Nomor 5 Tahun 2005 tentang Pemberdayaan Industri Pelayaran Nasional dan diberbagai peraturan peraturan lainnya.

Pada awalnya melalui ketentuan Pasal 131 UU Pelayaran, pembentuk undang-undang hendak menjadikan UU Pelayaran sebagai satu-satunya peraturan yang mengatur hipotik kapal laut. Namun di satu sisi, ketentuan mengenai hipotik kapal laut yang diperintahkan masih diatur dalam peraturan pemerintah sampai dengan saat ini belum diterbitkan undang-undang nya. Bahwa dengan mengeyampingkan peraturan yang sudah ada tanpa membentuk peraturan pelaksanaannya atau penggantinya, akan menyebabkan kekosongan hukum. Kekosongan hukum itulah yang menyebabkan PP Perkapalan "memberlakukan kembali" aturan-aturan mengenai Hipotik dalam KUHPerdata dan KUHD, yang dirasa lebih komprehensif dibandingkan dengan UU Pelayaran dan PP Perkapalan itu sendiri. ${ }^{10}$

Pemberlakuan kembali KUHPerdata dan KUHD merupakan langkah tepat dalam mengisi kekosongan hukum, namun demikian tata cara pemberlakuan kembali ke dua peraturan tersebut melalui peraturan setingkat peraturan pemerintah adalah tidak tepat dan melanggar asas-asas pembentukan peraturan perundang-undangan. Pemberlakuan ke dua peraturan tersebut, seharusnya melalui peraturan setingkat dengan undang-undang.

\footnotetext{
${ }^{9}$ Ibid., hlm. 14

10 Aktieva Tri Tjitrawati, Op.cit, hlm. 111.
} 
Selain itu, ketentuan KUHPerdata dan KUHD juga belum lengkap mengatur mengenai hipotik kapal laut, karena tidak mengatur secara khusus mengenai eksekusi hipotik kapal laut yang berada di luar wilayah Indonesia . Walaupun Indonesia telah meratifikasi International Covention on Maritime Liens and Mortgage 1993, melalui Peraturan Presiden Nomor 44 Tahun 2005, dan telah melakukan perubahan UU Pelayaran pada tahun 2008, maka UU Pelayaran 2008 dianggap sebagai Lex Spesialis dari KUHPerdata dan KUHD yang khusus mengatur hipotik kapal laut. Namun demikian peraturan tersebut juga belum mampu mengisi kekosongan hukum yang dibutuhkan oleh para pelaku dalam aktivitas bisnis pelayaran, sementara di sisi lain, lembaga keuangan dan perbankan membutuhkan landasan hukum yang memadai untuk meningkatkan kepercayaan mereka akan pengembalian dana pengadaan kapal. ${ }^{11}$

Banyaknya peraturan yang mengatur hipotik kapal laut, maka menyebabkan bangunan hukum jaminan kapal laut menjadi rapuh dan dalam prakteknya akan menghadapi kesulitan untuk menegakkan kepastian hukum yang pada ujungnya akan dapat menghambat akses globalisasi dan pembangunan, karena masih belum adanya peraturan khusus yang mengatur tentang hipotik itu sendiri. ${ }^{12}$

Dalam keadaan demikian, agar hukum jaminan hipotik dapat mempengaruhi perkembangan pembiayaan kapal laut secara positif, dan memberikan kepastian dan perlindungan hukum bagi pihak-pihak yang terlibat yang ujungnya dapat mensejahterakan masyarakat, khususnya masyarakat maritim, maka hipotik kapal laut harus diatur secara khusus dalam satu peraturan yang berjenjang sesuai dengan kebutuhan.

\section{Peranan Perbankan dalam Hipotik Kapal Laut}

Pembangunan sektor keuangan, sangat diharapkan dapat membawa perubahan yang positif bagi perekonomian Nasional. Perbankan memiliki peranan yang sangat penting terhadap pergerakan roda perekonomian di Indonesia, karena bank dapat optimal menjalankan perannya sebagai lembaga keuangan intermediasi.

Peranan intermediasi lembaga perbankan sangat berpengaruh pada pertumbuhan perekonomian suatu negara. ${ }^{13}{ }^{14}$ Bank dapat dikatakan sebagai darahnya suatu perekonomian negara. ${ }^{15}$ Kemajuan suatu bank disuatu negara dapat pula dijadikan ukuran kemajuan negara yang bersangkutan. Semakin maju suatu negara semakin besar peranan perbankan dalam mengendalikan negara tersebut.

Bank dalam menjalankan kegiatan usahanya harus berpedoman pada prinsip kehati-hatian, sebagaimana diatur dalam Pasal 8 Undang-undang Nomor 10 tahun 1998 tentang Perbankan, yang mengatur:

\footnotetext{
${ }^{11}$ Ibid

12 Mariam Darus Badrulzaman, Serial Hukum Perdata II Kompilasi Hukum Jaminan, cetakan ke I, Jakarta: Mandar Maju, 2004.

${ }^{13}$ Etty Mulyati, Kredit Perbankan,Aspek Hukum dan Pengembangan Usaha Mikro kecil dalam Pembangunan Perekonomian Indonesia, Bandung: Refika Aditama, 2016, hlm.69.

14 Sutan Remy Sjahdeini, Kebebasan berkontrak dan Perlindungan Seimbang Bagi Para Pihak Dalam Perjanjian kredit Bank di Indonesia, Jakarta: Institut Bankir Indonesia, 1993, hlm.183.

${ }^{15}$ Kasmir, Dasar-dasar perbankan, Jakarta: Raja Grafindo Persada, 2014, hlm.2.
} 
a. Dalam pemberian kredit atau pembiayaan berdasarkan prinsip syari'ah, bank umum wajib mempunyai keyakinan berdasarkan analisis yang mendalam atas itikad baik dan kemampuan serta kesanggupan nasabah debitur untuk melunasi utangnya serta kesanggupan nasabah debitur untuk melunasi utangnya atau mengembalikan pembiayaan dimaksud sesuai dengan yang diperjanjikan;

b. Bank umum wajib memiliki dan menerapkan pedoman perkreditan dan pembiayaan berdasarkan prinsip syari'ah, sesuai dengan ketentuan yang ditetapkan oleh Bank Indonesia.

Menurut Surat Keputusan Pasal 2 ayat (1) Direksi Bank Indonesia Nomor 23/69/Kep/Dir, tanggal 28 Februari 1991 tentang Jaminan Pemberian Kredit Keyakinan bank atas kesanggupan debitur untuk melunasi kredit sesuai dengan yang diperjanjikan disebut juga sebagai jaminan. Bahwa untuk memperoleh keyakinan tersebut, maka bank sebelum memberikan fasilitas kredit harus melakukan penilaian yang seksama terhadap watak, kemampuan, modal, agunan (jaminan) dan prospek usaha dari debitur. Dengan demikian adanya pemberian fasilitas kredit, digantungkan dengan adanya jaminan, baik itu jaminan berupa penilain terhadap watak, kemampuan, modal dan prosepek usaha, maupun jaminan berupa agunan, baik yang bersifat kebendaan maupun perorangan.

Upaya untuk meningkatkan pembangunan ekonomi telah dilakukan oleh bank dengan menawarkan berbagai ragam perkreditan, termasuk kredit pembiayaan pembelian atau perbaikan kapal laut, yang dijamin dengan kapal laut itu sendiri dengan jaminan hipotik. ${ }^{16}$ Untuk mewujudkan hal tersebut diharapkan tatanan aturan hukum mengenai Hipotik dengan objek jaminan kapal laut hendaknya dapat mampu meningkatkan kepercayaan lembaga keuangan atau bank untuk mendanai pengadaan kapal, mengingat usaha pelayaran di Indonesia dianggap belum fleksibel secara ekonomi, mengingat harga kapal yang tinggi dan juga risikonya apabila kredit macet, karena kapal laut tidak mudah dijual, dan dieksekusi apabila kapal laut berada di luar Indonesia sebagai negara pendaftaran kapal.

Namun demikian dengan adanya satu peraturan yang khusus tentang hipotik kapal laut, termasuk di dalamnya mengatur mengenai eksekusi kapal laut di luar wilayah Indonesia, maka bank tidak akan ragu lagi menyalurkan kreditnya dengan jaminan kapal laut. Meningkatnya kepercayaan bank terhadap pembiayaan pengadaan kapal laut, akan berdampak pada kelancaran angkutan laut dan selanjutnya akan membantu pencapaian sasaran Pembangunan Nasional melalui pengembangan potensi ekonomi yang ada. ${ }^{17}$

${ }^{16}$ Mariam Darus Badrulzaman, Bab-bab Tentang Hipotik, Bandung: Citra Aditya Bakti, 1991, hlm.101-102

${ }^{17}$ Herry Gunawan, Pengantar Transportasi dan Logistik, Jakarta: Raja Grafindo Persada, 2014, hlm. 100. 


\section{Hipotik Kapal Laut Dalam Mencapai Negara Kesejahteraan}

Hypotheca berasal dari bahasa latin, dan hypotheek dari bahasa Belanda, yang mempunyai arti "Pembebanan". ${ }^{18}$ Hipotik merupakan hak kebendaan atas benda tidak bergerak yang timbul karena perjanjian, yaitu suatu bentuk jaminan yang harus diperjanjikan terlebih dahulu. Hipotik sebagai hak kebendaan hanya terbatas pada hak untuk mengambil penggantian dari benda tidak bergerak bersangkutan untuk pelunasan suatu perikatan saja. ${ }^{19}$

Kondisi saat ini, belum ada Undang-undang yang secara khusus mengatur mengenai hipotik kapal laut. Undang-undang Hipotik Kapal yang telah disusun oleh Departemen Perhubungan dan telah dikirimkan kepada Departemen Hukum dan Hak Asasi Manusia, sejak tanggal 12 September 2005, ${ }^{20}$ hingga saat ini masih dalam pembahasan di Departemen Hukum dan Hak Asasi Manusia. Tersebarnya peraturan mengenai hipotik kapal laut di berbagai peraturan perundang-undangan dari berbagai hierarkinya, menyebabkan inefisiensi dan ketidak efektifan hukum. Bahkan UU Pelayaran 2008 yang merupakan Lex Spesialis dari peraturan mengenai hipotik kapal laut yang diatur dalam KUHPerdata dan KUHD, ternyata belum mampu mengisi kekosongan hukum, sementara di sisi lain, lembaga keuangan dan perbankan membutuhkan landasan hukum yang memadai untuk meningkatkan kepercayaan mereka atas pembiayaan kapal laut yang terkait dengan pengembalian dana pengadaan kapal. ${ }^{21}$

Oleh karena itu dalam rangka upaya pemerintah mengembangkan armada nasional, perlu segera dibentuk Undang-undang hipotik kapal laut, yang utamanya dimaksudkan untuk memberikan kepastian hukum bagi kreditur, dengan menyederhanakan antara lain prosedur pemasangan, pendaftaran, peralihan, pencoretan dan eksekusi hipotek atas kapal, termasuk mengakomodir norma-norma hukum Internasional di bidang maritim, antara lain International Convention on Maritime Liens and Ship Mortgages 1993 dan International Convention on Arrest of Ships 1999.

Pokok-pokok materi yang diharapkan diatur dalam Rancangan UndangUndang (RUU) antara lain meliputi : klaim-klaim maritim yang didahulukan; obyek hipotik atas kapal; asas-asas hipotik; pemberi dan penerima hipotik atas kapal; tata cara pemberian, pendaftaran, peralihan dan hapusnya hipotik atas kapal; eksekusi hipotik atas kapal; pencoretan hipotik atas kapal; sanksi administratif.

Khusus terkait aturan mengenai debitur cidera janji, di dalam rancangan undang-undang, harus diatur kreditur dapat menguasai kapal; menjual kapal melalui pelelangan umum; dan berhak menahan atau menyita kapal yang dibebani hipotik melalui pengadilan di Indonesia dan pengadilan di luar wilayah Indonesia, di mana tempat kapal berada, dan mengajukan permohonan ke pengadilan untuk memerintahkan agar kapal dijual secara paksa.

\footnotetext{
18john Salindeho, Sistem Jaminan Kredit Dalam Era Pembangunan Hukum, Cetakan Pertama, Jakarta: Sinar Grafika, 1994, hlm. 20

${ }^{19}$ Hartono Hadisoeprapto, Pokok-Pokok Hukum Perikatan dan Jaminan, Yogyakarta: Liberty, 1984,hlm. 61

${ }^{20} \mathrm{http}$ ://www.hukumonline.com yang diakses pada tanggal 8 februari 2017 Pukul 09.00 WIB.

${ }^{21}$ Aktieva Tri Tjitrawati, Op.cit, hlm. 111.
} 
Dialogia luridica: Jurnal Hukum Bisnis dan Investasi

Volume 10 Nomor 2, April 2019

Pengaturan hipotik kapal laut yang efektif, akan berbanding lurus dengan meningkatnya kredit dengan hipotik kapal laut, karena kredit yang disalurkan bank mendapatkan kepastian dan perindungan hukum. Hal ini sesuai dengan prinsip dalam Negara Kesejahteraan, yang merupakan suatu bentuk pemerintahan demokratis yang menegaskan bahwa negara bertanggung jawab terhadap kesejahteraan rakyat. Negara Kesejahteraan mengandung unsur sosialisme, mementingkan kesejahteraan rakyat di berbagai bidang terutama bidang hukum dan bidang ekonomi. Di bidang hukum, maka hukum yang ada harus disesuaikan dengan perkembangan sosial masyarakat. Kunci pokok dalam Negara Kesejahteraan adalah isu mengenai jaminan kesejahteraan rakyat oleh negara.

\section{KESIMPULAN}

Peranan Hukum Jaminan dalam meningkatkan kesejahteraan masyarakat suatu negara sangatlah signifikan karena menunjang kemajuan ekonomi dan kemajuan pembangunan pada umumnya terutama yang berkaitan dengan kegiatan perbankan karena terkait dengan pemberian kredit yang dilakukannya. Untuk mewujudkan kesejahteraan rakyat, negara memberikan landasan hukum yang memadai yang dapat memberikan kepastian dan perlindungan hukum untuk meningkatnya kepercayaan bank, sehingga penyaluran kredit dengan hiptoik kapal laut terjamin secara hukum. Pembiayaan pengadaan kapal laut, akan berdampak pada kelancaran angkutan laut dan selanjutnya akan membantu pencapaian sasaran pembangunan nasional, yang pada akhirnya tujuan negara kesejahteraan akan tercapai.

Hipotik kapal laut harus diatur dalam peraturan yang khusus untuk menjamin kepastian hukum. Peraturan yang ada saat ini masih tersebar secara partial dalam berbagai peraturan perundang-undangan. Hal ini tidak menguntungkan bank dalam menyalurkan kredit dengan objek jaminan hipotik berupa kapal laut. Salah satu peraturan yang dapat menjamin pemberian kredit dengan jaminan kapal laut, adalah mengenai eksekusi kapal laut, apabila kapal berada di luar wilayah Indonesia dan hukum acara pelaksanaannya. Terjaminnya kepastian hukum akan meningkatkan pemberian kredit, sehingga negara telah melaksanakan prinsipprinsip dalam Negara Kesejahteraan.

\section{DAFTAR PUSTAKA}

\section{Buku}

Anthony Giddens, The Third Way : Jalan Ketiga Demokrasi Sosial, Jakarta: Gramedia, 1998.

B. Hestu Cipto Handoyo, Hukum Tata Negara Indonesia, Menuju Konsolidasi Sistem Demokrasi, Jakarta: Universitas Atmadjaya, 2009.

Bahder Johan Nasution, Metode Penelitian Ilmu Hukum, Bandung: Mandar Maju, 2008.

Etty Mulyati, Kredit Perbankan,Aspek Hukum dan Pengembangan Usaha Mikro kecil dalam Pembangunan Perekonomian Indonesia, Bandung: Refika Aditama, 2016.

Hartono Hadisoeprapto, Pokok-Pokok Hukum Perikatan dan Jaminan, Yogyakarta: Liberty, 1984. 
Dialogia luridica: Jurnal Hukum Bisnis dan Investasi

Volume 10 Nomor 2, April 2019

Herry Gunawan, Pengantar Transportasi dan Logistik, Jakarta: Raja Grafindo Persada, 2014.

John Salindeho, Sistem Jaminan Kredit Dalam Era Pembangunan Hukum, Jakarta: Sinar Grafika, 1994.

Kasmir, Dasar-dasar perbankan, Jakarta: Raja Grafindo Persada, 2014.

Luthfi J. Kurniawan (et.al), Negara Kesejahteraan dan Pelayanan Sosial, Malang: Intrans Publishing, 2015.

M.Bahsan, Hukum Jaminan dan Jaminan Kredit Perbankan Indonesia, Jakarta: Raja Grafindo Persada, 2007..

Mariam Darus Badrulzaman, Bab-bab Tentang Hipotik, Bandung: Citra Aditya Bakti, 1991.

Mariam Darus Badrulzaman, Serial Hukum Perdata II Kompilasi Hukum Jaminan, cetakan ke I, Jakarta: Mandar Maju, 2004.

Moch Isnaeni, Hukum Jaminan Kebendaan, eksistensi, fungsi dan pengaturan, Surabaya: Laksbang Pressindo, 2016.

Otje Salman S dan Anton F Susanto, Teori Hukum (mengingat, mengumpulkan dan membuka kembali), Bandung: Refika Aditama, 2004.

Soerjono soekanto dan Sri Mamudji, Penelitian Hukum Normatif suatu tinjauan singkat, Jakarta: Raja Grafindo Persada, 1994.

Sutan Remy Sjahdeini, Kebebasan berkontrak dan Perlindungan Seimbang Bagi Para Pihak Dalam Perjanjian kredit Bank di Indonesia, Jakarta: Institut Bankir Indonesia, 1993.

\section{Internet}

Jimly Asshiddiqie, Gagasa Negara Hukum Indonesia, diakses dari http://www.jimly.com/makalah/namafile/135/Konsep_Negara_Hukum_Ind onesia.pdf.

http://www.hukumonline.com 